\title{
The Effect of Teacher Candidates' Critical Literacy Levels on Their Media Literacy Levels
}

\author{
Nuriye Semerci*, Çetin Semerci \\ Educational Sciences Department, Faculty of Education, Bartın University, Turkey
}

Copyright $\bigcirc 2017$ by authors, all rights reserved. Authors agree that this article remains permanently open access under the terms of the Creative Commons Attribution License 4.0 International License

\begin{abstract}
The purpose of this study is to determine the effect of teacher candidates' critical literacy levels on their media literacy levels. In the study, general survey model was used. The working group consists of 565 students studying at various departments of Bartın University, Faculty of Education. 'Media Literacy Level Determination Scale' developed by Karaman and Karataş (2009) and 'The scale of Critical Literacy' developed by Yilmaz (2013) were used in this study. According to the results of the path analysis which is conducted to determine the effect of the critical literacy of teacher candidates on their media literacy, it is seen that the $t$ values related to the variables of media literacy and critical literacy are significant at .05 level. In addition, it is seen that $\mathrm{p}$ value related to $\mathrm{x}^{2}$ value is significant in the model which critical literacy affects media literacy.
\end{abstract}

Keywords Teacher Candidates, Critical Literacy, Media Literacy

\section{Introduction}

Literacy is defined as the state of being literate in Turkish Dictionary (TDK, 2017). In this respect, literacy is related to reading and writing written texts (Sezer \& Sert. 2013, 67). However, this definition is not enough to explain the term literacy today. Today, literacy, which used to involve decoding the letters on paper, has transformed into literacy based on interpreting (Kurudayığlu \& Tüzel, $2010,284)$. The advances in technology, production and expansion of knowledge not only from print resources but also from various others changed the meaning of the concept of literacy and different types of literacy arose. Media literacy, which is one of those types of literacy, can be defined as using mass media tools according to one's own needs, accessing the contents in those tools (Aydoğdu \& Illhan, 2015, 54), understanding the messages in the media correctly and analysing and evaluating these messages correctly and consciously (Kurt \& Kürüm, 2010,
21). Media literacy can also be defined as the society's knowledge on the functioning of the mass media tools. However, this knowledge should include all dimensions of the functioning of media such as the economic grounds, organizational structures, psychological impacts and social results (Messaris, 1998). In other words, it can be defined as accessing the messages in print and non-print television, cinema, internet etc. and the competence to evaluate and communicate these messages (Manzo, 2007; Gomez \& Gomez, 2007).

Media literacy requires using the media effectively and wisely and questioning whether the presented information is correct or not (Aydoğdu \& İlhan, 2015, 54). In other words, it is important to have a critical point of view and to question knowledge. Media makes life easier for people but on the other hand, it could lead people to be exposed to unnecessary, incorrect and imperfect knowledge. At this point, it is necessary to question, criticize and search if the information is correct rather than just accepting it (Kılınç \& Potur, 2014). Therefore, it is necessary to combine and use media literacy with critical literacy.

Within the theory of critical pedagogy, critical literacy is one of the literacies that involve not only knowing reading and writing but also reading, writing, thinking and reacting (Kılınç and Potur, 2014). Critical literacy can be defined as the ability to question, examine and comprehend a text. It is going back to the text while reading, questioning the text and the author of the text, analysing and examining and explaining how texts shape the values and beliefs of the individuals (Curdt-Christiansen, 2010). It is difficult to interpret texts objectively. It is important to recognize the messages related to race and gender. As critical literacy develops individuals become more conscious (Mkandawire \& Walubita, 2015). Potur (2014, 808) indicates that the purpose of critical literacy is increasing the critical and social awareness of the students. Critical literacy is based on individual, socio-political, economic and intellectual research (Bishop, 2014). Critical literacy provides individuals with the tools they need to think in-depth about the texts they see. They push them to read what is given in between the lines and to look beyond what 
is seen to find out the existing and missing things (Ministry of Education of Ontario, 2006, 9). Critical literacy is a way of evaluation in terms of identifying the text (McLaughlin, \& DeVoogd, 2004, cited in. McLeod \& Vasinda, 2008, 261).

Using media literacy and critical literacy together is quiet effective for individuals to keep themselves safe, increase their awareness and understand and support the messages given correctly. However, it is seen that the news in the media are only watched without analysing and the reactions are developed accordingly (Şahin \& Tüzel, 2011; Başaran, 2005; Kıncal \& Kartal, 2009). At this point, teachers have a big responsibility. Both literacies should be developed starting from an early age and this should be one of the main purposes of curricula. Therefore, institutions education teachers should educate them accordingly. It can be said that teachers in the United States of America and the UK are not educated well enough on media education (Binark \& Bek, 2007). As in Turkey (Y1lmaz, 2013), media literacy is taught with a protectionist approach rather than critical approach.

The purpose of this study, which is about the relationship between media literacy that all individuals are expected to have and critical literacy, is to determine "the impact of the critical literacy levels of teacher candidates on their media literacy levels". In the light of this purpose, the relationship between critical literacy and media literacy are examined based on gender, department and grade level.

\section{Method}

In the current study, correlational survey method is used to determine the relationship between media literacy and critical literacy. The purpose is to determine the existing condition.

\section{Study Group}

The study group is 565 students studying at the Faculty of Education at Bartın University. Information about the students are given in Table 1.

Of the participating students, $63 \%$ are female and $37 \%$ are male. The breakdown of the students based on the departments they study are as given: $15.8 \%$ (89) study Physical Education and Sports Teaching, 22,5\% (127) Primary Education, $10,4 \%$ (59) study Science Teaching, $25 \%$ (145) study Social Studies Teaching, 12.0\% (68) study Turkish Language Teaching and 13.6\% (77) study Elementary Mathematics Education. And of all participating students, $42.3 \%$ are freshman, $23.5 \%$ are sophomore, $17,7 \%$ are junior and $16.5 \%$ are senior class students.
Table 1. Study group features

\begin{tabular}{|c|c|c|c|}
\hline & & $\mathrm{f}$ & $\%$ \\
\hline \multicolumn{4}{|l|}{ Gender } \\
\hline Female & & 357 & 63.0 \\
\hline \multirow[t]{2}{*}{ Male } & & 208 & 37.0 \\
\hline & Total & 565 & 100.0 \\
\hline \multicolumn{4}{|l|}{ Department } \\
\hline Physical education and sports & & 89 & 15.8 \\
\hline Science education & & 59 & 10.4 \\
\hline Elementary mathematics & & 77 & 13.6 \\
\hline Primary education & & 127 & 22.5 \\
\hline Social studies & & 145 & 25.0 \\
\hline \multirow[t]{2}{*}{ Turkish language teaching } & & 68 & 12.0 \\
\hline & Total & 565 & 100.0 \\
\hline \multicolumn{4}{|l|}{ Class } \\
\hline 1. & & 239 & 42.3 \\
\hline 2. & & 133 & 23.5 \\
\hline 3. & & 100 & 17.7 \\
\hline 4. & & 93 & 16.5 \\
\hline & Total & 565 & 100.0 \\
\hline
\end{tabular}

\section{Collection and Analysis of Data}

In collecting the data in the study, "Media Literacy Levels Scale" (Karaman and Karataş, 2009) and "Critical Literacy Scale" (Y1lmaz, 2013) are used.

"Media Literacy Levels Scale" includes 17 items and three factors. The Cronbach Alpha coefficient of the scale is ,840. The Cronbach alpha values for the factors are as follows: ,721 for "Having Information" factor, ,705 for "Being able to analyse and form reaction" factor and ,680 for "Being able to judge and recognize implicit messages" factor. It is a five-point likert type scale and the questions are scaled as; " $1=$ Never, 2= Rarely, 3= Sometimes, $4=$ Frequently and $5=$ Always" (Karaman \& Karataş, 2009).

Critical Literacy Scale has 14 items and two factors. There are options to determine the frequency of behaviours related to critical literacy. These are scaled as; " $1=$ Never, $2=$ Rarely, $3=$ Sometimes, $4=$ Frequently and $5=$ Always". The KMO of the scale is found as 0,884; Bartlett test as 2055,293 and sd as $91(\mathrm{p}=0,000)$. The Cronbach Alpha value of the scale is 0.82 ; and it is 0,76 for the "Critical Reading" factor of the scale and 0,71 for the "Critical writing" factor of the scale (Y1lmaz, 2013).

\section{Analysis of Data}

In analysing the data, t-test is used for pairwise comparisons, analysis of variance is used for multiple comparisons and path analysis is used when looking into the relationships.

\section{Findings}

T-test results showing the relationship between media literacy and critical literacy depending on gender are given in table below: 
Table 2. $\mathrm{t}$-test results between critical literacy and media literacy according to gender

\begin{tabular}{|c|c|c|c|c|c|c|c|}
\hline & Gender & $\mathbf{N}$ & Mean $(\bar{X})$ & Std. Dev. & Sd & t & p \\
\hline \multirow{3}{*}{ Media Literacy } & Female & 357 & 3.70 & 0.60 & 563 & $0.570 *$ & 0.569 \\
\cline { 2 - 8 } & Male & 208 & 3.67 & 0.52 & & & \\
\hline \multirow{2}{*}{ Critical Literacy } & Female & 357 & 3.65 & 0.55 & 563 & $0.550 *$ & 0.090 \\
\cline { 2 - 8 } & Male & 208 & 3.57 & 0.56 & & & \\
\hline$* \mathrm{P}>0.05$ & \multicolumn{7}{|l}{} \\
\hline
\end{tabular}

There is no statistically significant difference between media literacy $(\mathrm{t}=0.570, \mathrm{Sd}=563, \mathrm{p}>0.05)$ and critical literacy $(t=0.570, S d=563, p>0.05)$ depending on gender. The student answers in media literacy and critical reading mostly fall under "frequently" answer. Accordingly, it is possible to say that students' critical reading and media literacy levels are high.

Table 3. Descriptives of critical literacy and media literacy in terms of department

\begin{tabular}{|c|c|c|c|c|c|c|c|}
\hline & & \multirow{2}{*}{$\mathrm{N}$} & \multirow{2}{*}{ Mean } & \multirow{2}{*}{ Std. Deviation } & \multirow{2}{*}{ Std. Error } & \multicolumn{2}{|c|}{$95 \%$ Confidence Interval for Mear } \\
\hline & & & & & & Lower Bound & Upper Bound \\
\hline \multirow{7}{*}{ Media Literacy } & Physical education and sports & 89 & 3,52 & 0,68 & 072 & 3,3791 & 3,6638 \\
\hline & Primary education & 127 & 3,53 & 0,54 & 048 & 3,4312 & 3,6203 \\
\hline & Science education & 59 & 3,75 & 0,61 & 079 & 3,5882 & 3,9053 \\
\hline & Social studies & 145 & 3,86 & 0,51 &, 042 & 3,7749 & 3,9411 \\
\hline & Turkish language teaching & 68 & 3,89 & 0,41 &, 050 & 3,7886 & 3,9882 \\
\hline & Elementary mathematics & 77 & 3,60 & 0,57 & 064 & 3,4668 & 3,7235 \\
\hline & Total & 565 & 3,69 & 0,57 & 024 & 3,6393 & 3,7338 \\
\hline \multirow{7}{*}{ Critical Literacy } & Physical education and sports & 89 & 3,59 & 0,67 & 071 & 3,4440 & 3,7261 \\
\hline & Primary education & 127 & 3,49 & 0,53 & 047 & 3,3975 & 3,5845 \\
\hline & Science education & 59 & 3,68 & 0,51 & ,066 & 3,5446 & 3,8089 \\
\hline & Social studies & 145 & 3,71 & 0,47 & ,039 & 3,6343 & 3,7883 \\
\hline & Turkish language teaching & 68 & 3,76 & 0,46 &, 055 & 3,6545 & 3,8749 \\
\hline & Elementary mathematics & 77 & 3,54 & 0,69 & 079 & 3,3825 & 3,6954 \\
\hline & Total & 565 & 3,62 &, 056 & ,024 & 3,5749 & 3,6676 \\
\hline
\end{tabular}

When students' critical literacy and media literacy levels are examined depending on the departments, it is seen that their answers fall under frequently option. When their means are compared, it is seen that the means of Turkish Language Teaching $(\bar{X}=3.89)$ and Social Studies Teaching $(\bar{X}=3.86)$ are higher compared to other departments. Whether there is a statistically significant difference in both media and critical literacy depending on the departments is tested and the results are given in Table 4.

Table 4. ANOVA findings of critical literacy and media literacy in terms of department

\begin{tabular}{|c|c|c|c|c|c|c|c|}
\hline & & Sum of Squares & df & Mean Square & $\mathrm{F}$ & Sig. & Scheffe/LSD \\
\hline \multirow{3}{*}{ Media literacy } & Between Groups & 13,602 & 5 & 2,720 & 8,904 &, 000 & $2-5,2-6,3-5,3-6$ \\
\hline & Within Groups & 170,788 & 559 & ,306 & & & \\
\hline & Total & 184,390 & 564 & & & & \\
\hline \multirow{3}{*}{ critical literacy } & Between Groups & 5,550 & 5 & 1,110 & 3,612 &, 003 & $2-6,3-4,3-5,3-6$ \\
\hline & Within Groups & 171,783 & 559 & ,307 & & & \\
\hline & Total & 177,333 & 564 & & & & \\
\hline
\end{tabular}


A statistically significant difference is found in both literacies depending on department. To find out between which departments this difference arose, Scheffe/LSD tests are conducted and the results indicate that there is a significant difference between Physical Education and Sports Teaching and Social Studies Teaching; Physical Education and Sports Teaching and Turkish Language Teaching in media literacy $(\mathrm{F}=8.904, \mathrm{p}<0.05)$. In addition, there is a significant difference found between Primary Education and Social Studies; and Primary Education and Turkish Language Teaching in media literacy $(\mathrm{F}=8.904, \mathrm{p}<0.05)$. As it is seen in the means, media literacy levels are high in Social Studies Teaching and Turkish Language Teaching Departments and lower in Physical Education and Sports Teaching and Primary Education. In critical literacy levels, statistically significant differences are found between Physical Education and Sports Teaching and Turkish Language Teaching; Primary Education and Science Teaching; Social Studies Teaching and Turkish Language Teaching Departments.

Table 5. Descriptives of critical literacy and media literacy in terms of grade level

\begin{tabular}{|c|c|c|c|c|c|c|c|c|c|}
\hline \multirow[b]{2}{*}{ Grade level } & & \multirow{2}{*}{$\mathrm{N}$} & \multirow{2}{*}{ Mean } & \multirow{2}{*}{ Std. Deviation } & \multirow{2}{*}{ Std. Error } & \multicolumn{2}{|c|}{$95 \%$ Confidence Interval for Mean } & \multirow{2}{*}{ Minimum } & \multirow{2}{*}{ Maximum } \\
\hline & & & & & & Lower Bound & Upper Bound & & \\
\hline \multirow{5}{*}{ Media literacy } & 1. & 239 & 3,6727 & ,60238 &, 03897 & 3,5959 & 3,7494 & 1,53 & 5,00 \\
\hline & 2. & 133 & 3,6979 &, 53256 &, 04618 & 3,6066 & 3,7893 & 2,00 & 5,00 \\
\hline & 3. & 100 & 3,6324 &, 54662 &, 05466 & 3,5239 & 3,7408 & 2,00 & 4,94 \\
\hline & 4. & 93 & 3,7641 &, 57193 &, 05931 & 3,6463 & 3,8819 & 2,24 & 5,00 \\
\hline & Total & 565 & 3,6865 &, 57178 &, 02405 & 3,6393 & 3,7338 & 1,53 & 5,00 \\
\hline \multirow{5}{*}{ Critical literacy } & 1. & 239 & 3,5950 & ,63812 & 04128 & 3,5137 & 3,6764 & 1,86 & 5,00 \\
\hline & 2. & 133 & 3,6740 & ,44349 & ,03846 & 3,5979 & 3,7501 & 2,50 & 4,64 \\
\hline & 3. & 100 & 3,5257 & ,55677 & ,05568 & 3,4152 & 3,6362 & 2,21 & 4,64 \\
\hline & 4. & 93 & 3,7158 & ,48330 & ,05012 & 3,6163 & 3,8154 & 2,00 & 4,64 \\
\hline & Total & 565 & 3,6212 &, 56073 & 02359 & 3,5749 & 3,6676 & 1,86 & 5,00 \\
\hline
\end{tabular}

When students' critical literacy and media literacy levels are examined depending on the grade level, it is seen that the answers of all grade levels fall under frequently option in both media literacy and critical literacy. When their means are compared, it is seen that the means of senior students have higher means compared to the rest of grade levels; and junior students have lower means compared to other grade levels. Whether there is a statistically significant difference between means are tested and the results are given in Table 6 .

Table 6. ANOVA findings of critical literacy and media literacy in terms of grade levels

\begin{tabular}{|c|c|c|c|c|c|c|}
\hline & & Sum of Squares & df & Mean Square & F & Sig. \\
\hline \multirow{4}{*}{ Media literacy } & Between Groups &, 916 & 3 &, 305 &, 934 &, 424 \\
\cline { 2 - 7 } & Within Groups & 183,474 & 561 &, 327 & & \\
\cline { 2 - 7 } & Total & 184,390 & 564 & 3,434 &, 064 \\
\cline { 2 - 7 } Critical literacy & Between Groups & 2,279 & 360 & & \\
\cline { 2 - 7 } & Within Groups & 175,054 & 561 &, 312 & & \\
\hline
\end{tabular}

According to Table 6, there is no statistically significant difference between media literacy and critical literacy depending on grade level. 


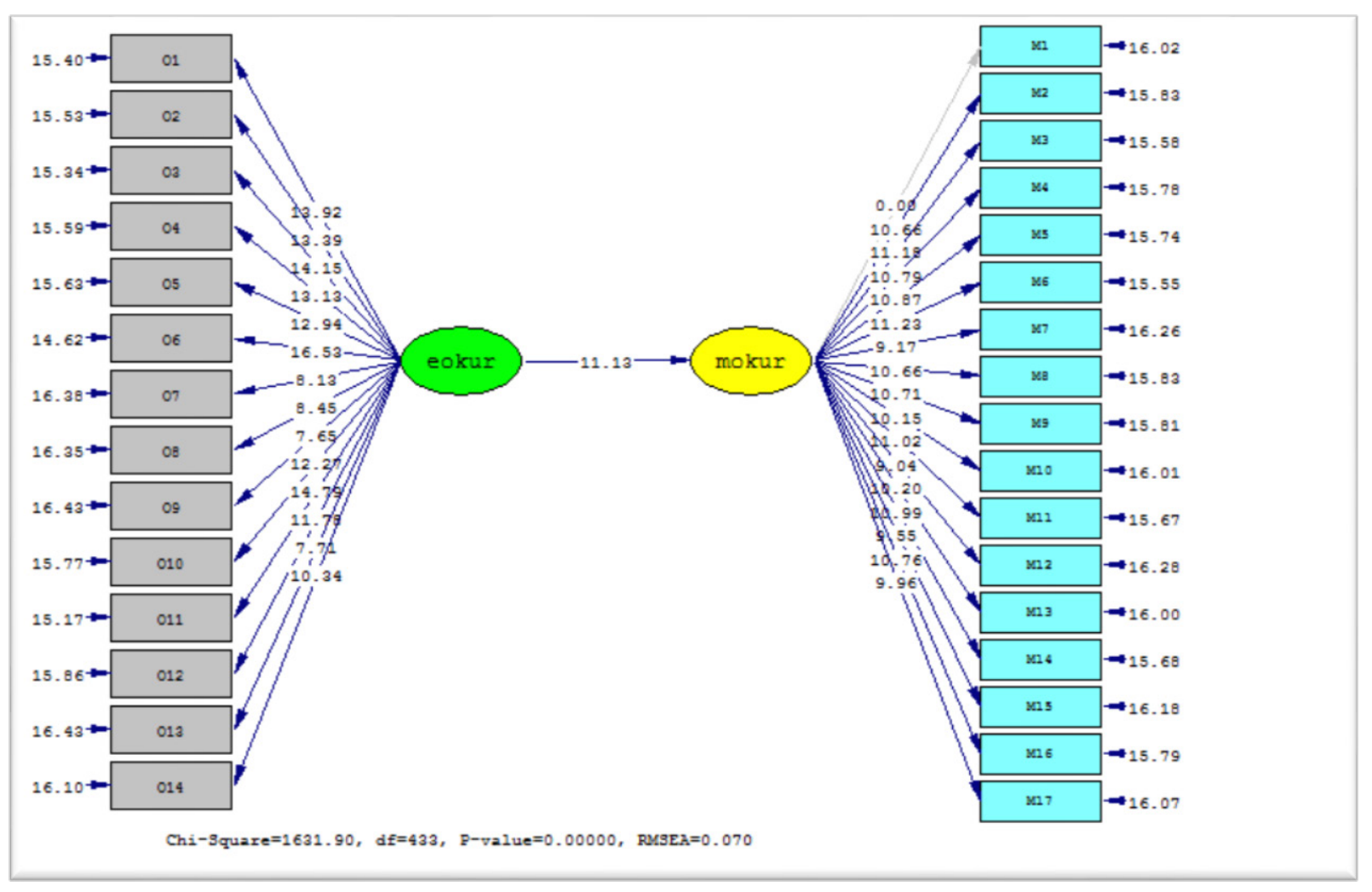

Figure 1. The t- value of the Model (evkur: Critical literacy, mokur: Media literacy)

The results of path analysis carried out to determine the impact of teacher candidates' critical literacy levels on their media literacies are given in Figure 1. When Figure 1 is examined, it is seen that the $t$ value related to media literacy and critical literacy variables is significant at .05 level. Besides, in the model in which the impact of critical literacy on media literacy is established, it is seen that the $p$ value of $x^{2}$ is significant. When the model is evaluated according to the ratio of $x^{2}$ and degree of freedom $\left(\mathrm{x}^{2} / \mathrm{sd}=1631,90 / 433=3,76\right)$, it can be expressed that the agreement is at a good level. When the goodness-of-agreement indices of the model were examined, the following values were found as $\mathrm{GFI}=.84$; AGFI .82; Standardized RMR $=.062$; CFI $=.95$; NFI $=.92$; $\mathrm{NNFI}=.94 ; \mathrm{IFI}=.95$ and $\mathrm{RMSEA}=.07$. When the agreement indices of the model are examined, it is seen that the model is compatible.

\section{Results, Conclusions and Recommendations}

The purpose of this study is to determine the effect of teacher candidates' critical literacy levels on their media literacy levels. In the study, students' answers in media literacy and critical reading mostly fall under "frequently" category. When students' critical literacy and media literacy levels are examined depending on the departments, it is seen that their answers fall under frequently option. A statistically significant difference is found in both literacies depending on department. To find out between which departments this difference arose, Scheffe/LSD tests are conducted and the results indicate that there is a significant difference between Physical Education and Sports Teaching and Social Studies Teaching; Physical Education and Sports Teaching and Turkish Language Teaching in media literacy.

When students' critical literacy and media literacy levels are examined depending on the grade level, it is seen that the answers of all grade levels fall under frequently option in both media literacy and critical literacy. As a result of path analysis, there is a significant relation between teacher candidates' critical literacy levels and on their media literacies.

Using media literacy and critical literacy together is quiet effective for individuals to keep themselves safe, increase their awareness and understand and support the messages given correctly (Şahin \& Tüzel, 2011; Başaran, 2005; Kincal \& Kartal, 2009). The result of the study indicates that students' media literacy and critical literacy levels are high. However, this finding should be supported by different studies.

\section{REFERENCES}

[1] Başaran, M. (2005). Sınıf öğretmeni adaylarının bilgi 
okuryazarlıklarının değerlendirilmesi. Gazi Eğitim Fakültesi Dergisi, 25(3), 163-177.

[2] Binark, M. \& Bek, G.M. (2007). Eleştirel Medya Okuryazarlığı Kuramsal Yaklaşımlar ve Uygulamalar. İstanbul: Kalkedon Yayınevi.

[3] Bishop, E. (2014). Critical Literacy Bringing Theory to Praxis, Journal of Curriculum Theorizing, 30 (1), 51-63,

[4] Curdt-Christiansen, X.L. (2010). Competing Priorities: Singaporean Teachers' Perspectives on Critical Literacy, International Journal of Educational Research, 49: 184 194.

[5] Gomez L.M. \& Gomez, K. (2007). Reading for learning: Literacy supports for 21 st-Century Work. P.D. KAPPAN.

[6] İlhan, E. \& Aydoğdu, E. (2015). Medya Okuryazarlığı Dersi ve Yeni Medya Algısına Etkisi, Erciyes Illetişim Dergisi "akademia", 4 (1), 52-68.

[7] K1lınç, A. \& Potur, Ö. (2014). Eleştirel Okuryazarlıkla İlişkilendirilmiş Türkçe Dersleriyle İlgili Öğrenci Algı ve Görüşleri, Mustafa Kemal Üniversitesi Sosyal Bilimler Enstitüsü Dergisi, 11 (27), 317-336.

[8] Kıncal, R.Y. \& Kartal, O.Y. (2009). Medya okuryazarlığ eğitimi, Milli Ĕgitim Dergisi. 181, 318-333.

[9] Kurt, A.A. \& Kürüm, D. (2010). Medya Okuryazarlığı ve Eleştirel Düşünme Arasındaki İlişki: Kavramsal Bir Bakış, Mehmet Akif Ersoy Üniversitesi Sosyal Bilimler Enstitüsü Dergisi, 2(2), 20-34.

[10] Kurudayığlu, M. \& TÜZEL, S. (2010). 21. Yüzyıl Okuryazarlık Türleri, Değişen Metin Algısı Ve Türkçe Eğitimi, Türklük Bilim Araştırmaları TÜBAR-XXVIII, 21, 283-298

[11] Manzo, K. K. (2007). Alliance provides 'core principles' for media literacy. Education Week, 26,42 .

[12] McLeod, J. \& Vasinda, S. (2008). Critical Literacy and Web 2.0: Exercising and Negotiating Power, Computers in the Schools, 25(3-4).

[13] Ministry of Education of Ontario (2006). Literacy for learning - The report of the expert panel on literacy in grades 4 to 6. Ontario: Ministry of Education.

[14] Mkandawire, M. T. ve Walubita, G. (2015). Feedback Study on Developing Critical Literacy among Malawian and Zambian Undergraduate University Students Using a Freirean Praxis, Journal of Education and Training Studies, 3(2). URL: http://jets.redfame.com. Redrieved August 2, 2017.

[15] Potur, Ö. (2014). Eleştirel Okuryazarlıkla İlişkilendirilmiş Türkçe Derslerinin Öğretim Süreci 2 Eğitimde Kuram ve Uygulama, Journal of Theory and Practice in Education, 10(4), 807-839

[16] Sezer, N. \& Y1lmaz Sert, N. (2013) Online Medya Okuryazarlığının Yetişkinler İçin Önemi "Online Haber Sitelerindeki Bannerlara Yönelik Bir İnceleme", Online Academic Journal of Information Technology, 4 (13), 63-78.

[17] Şahin, Ç. \& Tüzel, S. (2011). Medya dünyasının gerçek dünyayı yansıtma düzeyinin öğretmen adaylarının görüşleri doğrultusunda belirlenmesi, Eğitim ve Bilim. 36(159), 127-140.

[18] TDK, (2017). Büyük Türkçe Sözlük, URL: $\mathrm{http}: / /$ www.tdk.org.tr/index.php?option=com_bts\&view $=\mathrm{bt}$ s. Redrieved August 2, 2017.

[19] Yılmaz, E (2013). Sınıf öğretmeni adaylarının gazete ve dergi takip etme alışkanlıkları ile eleştirel ve medya okuryazarlık düzeyleri arasındaki ilisski. Yayımlanmamıs Yüksek lisans Tezi, Adnan Menderes Üniversitesi, Aydın. 